\title{
Kota Sebelum Mesin: Yogyakarta Periode 1950an-1970an
}

\author{
EKA RAHAYU MANGGASARI
}

Alumnus S1 Sejarah UGM

Email: ekarahayuma@gmail.com

\begin{abstract}
This study discusses the history of the Indonesian city from the perspective of the pedicab peddlers from the 1950s to the 1970s. The role of the pedicab peddlers was central in transporting people and goods in the cities. The stagnation of public transportation, which had started since the Japanese occupation, had worsened in the postcolonial period. The failure to find a substitute for public transport resulted in its replacement with human labor, in the form of the pedicab. The article argues that the centrality of the pedicab during the early decades of independence means that to understand how urban spaces were experienced required an understanding of their function for these urban spaces. Their role need to be given voice to the narrative of the city. Pedicabs worked in tehe urban streets and are integral to the functioning of the street. The article wants to explore the writing of the history of the city, in which human power plays a central role. In depth the purpose of this kind of writing will open our eyes to our understanding of how the city works at the street level.
\end{abstract}

\begin{abstract}
Abstrak
Penelitian ini membahas tentang sejarah kota dengan sudut pandang para pengayuh becak tahun 1950an hingga 1970an. Pada tahun tersebut peran pengayuh becak berada pada posisi yang sentral. Akibat kesulitan bahan bakar dan mandeknya fungsi transportasi umum di kota, yang sudah terjadi pada periode zaman pendudukan Jepang dan semakin parah pada periode selanjutnya. Ditambah pula dengan gagalnya subtitusi transportasi dari mesin ke hewan (kuda), akibat kesulitan dalam hal pakan dan perawatan sehingga sebagian dari mereka banyak yang mati. Namun pada awal kemerdekaan kegagalan subtitusi tersebut berhasil digantikan oleh tenaga manusia dalam bentuk transportasi becak. Untuk itu, dalam memahami sejarah kota pada tahun 1950an hingga 1970an secara menyeluruh dan mendalam, tidak bisa tanpa memahami keberadaan mereka. Keberadaan mereka yang sentral perlu diberikan panggung dalam narasi sejarah kota. Pengayuh becak sebagai pekerja sektor informal mayoritas merupakan migran dari desa yang ber-urbanisasi ke kota. Sebagai pengayuh becak di kota, mereka harus melakukan hubungan sosial dengan pemilik perusahaan becak dan pelanggannya yang merupakan penghuni kota. Melalui hubungan-
\end{abstract}

\section{Keywords:}

Desakota;

Urban Society;

Informal

Sector;

Pedicab; Social

Relations;

Streets

Kata kunci:

Desakota; Masyarakat Urban; Sektor informal; Becak; Hubungan sosial; Jalanan 
hubungan tersebut tercipta aktivitas sosial yang menunjang kebutuhan kota. Sedangkan untuk dapat menjalankan aksinya, pengayuh kota tak bisa dilepaskan oleh fungsi jalanan. Oleh karena itu, melalui pendekatan pengayuhnya, penulis ingin mengeksplorasi penulisan sejarah kota, yang mana tenaga manusia memiliki peran yang sentral. Secara mendalam tujuan dari penulisan semacam ini akan membuka mata kita terhadap pemahaman kita cara kerja kota di level jalanan.

\section{Pengantar}

Artikel ini merupakan akan membahas sejarah sehari-hari (everyday history) dari sudut pandang kelompok subaltern perkotaan Indonesia; yaitu tukang becak. Tukang becak mendominasi jalanan perkotaan Indonesia pada tahun 1950an sampai 1970an sebagai akibat dari keterbatasan transportasi publik serta murahnya tenaga kerja jasa informal pada periode tersebut. Artikel dibagi menjadi dua. Bagian awal menjelaskan perubahan struktural yang mendorong migrasi pedesaan kepada perkotaan. Hal ini menjelaskan kemunculan dan penguatan fenomena becak. Kedua adalah pendekatan etnografis untuk memahami ruang-ruang perkotaan dari sudut pandang tukang becak, pelanggan dan perusahaan becak.

Sejarah kota Indonesia telah mendapat perhatian oleh banyak sejarawan dan peneliti Indonesia maupun luar negeri. Salah satu perhatian dari banyak penelitian tentang sejarah kota pada periode tersebut ialah pada aspek perubahan sosial. Clifford Geertz dalam bukunya The Social History of an Indonesian Town, memperlihatkan bagaimana transformasi sosial masyarakat di kota (Clifford Geertz, 1965). Selain itu, W.F. Wertheim dalam bukunya yang sudah diterjemahkan ke dalam bahasa Indonesia Masyarakat Indonesia dalam Transisi. menunjukkan perubahan masyarakat dari pola desa menuju pola kota, yaitu perubahan dari masyrakat agraris menuju masyarakat modern (W.F. Wertheim, 1999). Artikel ini tidak ingin memasuki narasi sejarah kota, melainkan memahami bagaimana orang-orang dalam kota mengalami kota dengan melakukan studi kasus industri becak.

Studi kasus dilakulkan di kota Yogyakarta. Selo Soemardjan dalam Perubahan Sosial di Yogyakarta membahas tentang perubahan dalam masyarakat di awal kemerdekaan munculnya dominasi kaum intelektual terdidik (Selo Soemardjan, 2009). Pembahasan kemunculan kaum terdidik juga diangkat dalam buku Sejarah Perkembangan Sosial Kota Yogyakarta oleh Abdurrahman Surjomihardjo (Abdurrahman Surjomihardjo, 2008). Pada periode selanjutnya, Djoko Suryo melalui tulisannya, Penduduk dan Perkembangan Kota Yogyakarta 1900-1990 mengangkat pula tentang peran kaum tersebut, bersama dengan birokrat priyayi, kaum profesional, dan pengusaha pada abad ke-20 yang ia sebut sebagai embrio lahirnya orang Indonesia (Djoko Suryo, 2015). Cepatnya perubahan sosial di Yogyakarta ini menjadikan pengalaman tukang becak di Yogyakarta representatif terhadap perubahan tingkat nasional. 
Sejarah perkotaan seringkali melihat pada perubahan dipelopori oleh golongan menengah ke atas. Tapi hal ini menghilangkan banyak fenomena perkotaan yang sebenarnya dialami oleh orang-orang dari golongan menengah ke bawah. Studi tentang golongan menengah kebawah seringnya fokus pada kampung dan masyarakat kampung. Tetapi sebenarnya, kegiatan perkotaan juga dilakukan dibagian-bagian lain kota; seperit jalanan. Untuk melengkapi dan menyeimbangkan berbagai penelitian yang sudah ada sebelumnya, penelitian ini mengangkat fenomena becak dan tukang becak pada 1950an hingga 1970an. Tukang becak hidup dalam jalanan dan sehingga memahami ruang kota dari sudut pandang mereka membuka bagian dari sejarah kota yang selama ini luput. Dalam memahami sejarah kota-kota Indonesia tahun 1950an-1970an tidak bisa tanpa memahami keberadaan mereka. Keberadaan tukang becak tidak bisa dipisahkan dengan pelanggan serta perusahaan becak. Tiga grup antara pelanggan, tukang becak dan perusahaan becak saling berhubungan dan saling terkait. Dengan melihat hubungan antara ketiga grup ini, transportasi perkotaan tidak hanya dilihat sebagai sarana penghubung tempat, melainkan juga masalah relasi antar orang yang dipertemukan di ruang kota, (Sunyoto Usman, 2015). Relasi terbentuk karena dalam kehidupan sehari-hari manusia sebagai makhluk sosial yang saling membutuhkan, dengan kepentingan masing-masing namun saling memberikan respon (Sunyoto Usman, 2015: 31).

\section{Kota Masa Transisi}

Pada periode tahun 1950an hingga 1970an kota-kota di Jawa mengalami urbanisasi. Artikel beranggapan bahwa penyebab utama dari urbanisasi ini diakibatkan oleh karena adanya perubahan dalam tata-kelola ekonomi kolonial, dari industri pertanian, khususnya industri gula, yang melihat investasi perekonomian kolonial di pedesaan menuju perekonomian pascamerdeka yang mana daerah pedesaan mengalaim proses deindustrialisasi. Proses deindustrialisasi pedesaan ini mengakibatkan terjadinya deteritorialisasi desa-kota yang mendorong adanya pencarian pekerjaan, khususnya pada sektor jasa, di perkotaan. Lingkaran konsentris desa sebagai wilayah yang melingkupi kota (pusat pemerintahan dan servis orang barat), serta desa sebagai tempat tersedianya lapangan pekerjaan bagi para petani (Peter J.M Nas, 2007: 300). Setelah kemerdekaan, terjadinya deindustrialisasi pedesaan di berbagai tempat, khususnya Yogyakarta dimana semua pabrik gula kolonial mengalami kehancuran pada masa Jepang dan Revolusi, dan dimana ada keenganan dari pemerintahan lokal untuk menerima investasi asing baru pada sektor perkebunan. Kasus Yogyakarta akan digunakan sebagai studi kasus untuk memahami efek deindustrialisasi pedesaan terhadap ruang-ruang perkotaan.

Deteritorialisasi desa-kota merupakan suatu gambaran memudarnya 
sekat kedua wilayah teritorial (desa-kota), sehingga masyarakat dengan leluasa keluar-masuk kota maupun desa. ${ }^{1}$ Pada awal abad ke-18 ketika kehadiran bangsa barat, wilayah pedesaan Indonesia merupakan areal pertanian. Bahwa pertanian dengan cara subsisten merupakan pekerjaan utama penghuninya. Para petani umumnya berproduksi guna memenuhi kebutuhan mereka sendiri, dan sebagian hasilnya diserahkan ke kota (dalam bentuk seserahan untuk raja atau pemimpin di wilayah itu). Sedangkan, kehadiran para pedagang Belanda, memanfaatkan sistem ekonomi tradisional tersebut, dengan menekankan penarikan upeti dari para pemimpin Indonesia (W.F. Wertheim, 1999: 67).

Perubahan fundamental ruang desa-kota di Jawa terjadi dengan penetrasi ekonomi kapitalis perkebunan yang berlangsung di wilayah pedesaan dibawah periode Gubernur Jenderal Daendels, Raffles dan Van Den Bosch. Sistem Tanam Paksa Van Den Bosch, mewajibkan penduduk untuk menanam tanaman pasar dunia. Pembalikan oleh pemerintah tersebut berdampak pada kehidupan desa, dan pengaruhnya melebihi hasil penguasa pribumi sebelumnya, yang membiarkan ekonomi desa dalam keadaan utuh (W.F. Wertheim, 1999: 68). Perluasan sistem tanam paksa menjadi sistem sawah untuk tujuan menyelingi penanaman padi dan tebu, membuat perubahan mendalam pada struktur desa. Ketika pemilikan swasta atas sawah muncul, hak-hak orang desa dipersempit dan kekuasaan pemimpin desa untuk mengatur lahan yang dapat ditanami semakin tinggi. Akibatnya, muncul kesenjangan sosial di wilayah pedesaan antara pemimpin desa dan petani penggarap. Kekuasaan pemimpin desa menjadi sangat kuat, sedangkan petani penggarap atau buruh tani tetap pada pekerjaannya, dan semakin terdesak ruang geraknya (W.F. Wertheim, 1999: 68).

Sudah sejak dari zaman kolonial petani penggarap maupun buruh tani berada pada posisi yang kurang menguntungkan. Meskipun pada akhir abad ke-19 pemerintah berupaya memberikan kontribusi positif bagi tercapainya kesejahteraaan penduduk pribumi melalui kebijakan "Politik Etis". Tetapi secara keseluruhan perjuangan ekonomi masih sulit bagi orang Jawa. Yaitu kekurangan lahan pertanian yang mendorong orang Jawa bermigrasi mencari pekerjaan di kota (W.F. Wertheim, 1999: 71). Migrasi orang Indonesia dari desa ke kota terus-menerus terjadi, terutama di kota-kota besar dan strategis (Rony G. Sunaryo, dkk, 2014: 22-23 ). Sensus penduduk pada 1920 mencatat bahwa 6,63 persen penduduk Jawa tinggal di kota. Pada periode ini, Jumlah tersebut semakin meningkat pada tahun 1930, penduduk yang tinggal di kota menjadi 8,7 persen (John Ingleson, 2013: 91). Dari jumlah tersebut, 3,8 persen tinggal di kota-kota yang berpenduduk lebih dari 100.000 jiwa (Purnawan Basundoro, 2013).

1) "Deteritorialisasi desa-kota" merupakan definisi yang dipilih penulis untuk menjelaskan fenomena yang terjadi pada kedua ruang tersebut pasca kolonial. 
Cikal bakal kota sebagai kerangka "harapan baru" mulai terbentuk. Sekat teritorial antara desa sebagai pusat perekonomian (tersedianya lapangan pekerjan), dan kota sebagai pusat pemerintahan serta servis penguasa barat jika diibaratkan tembok, sedikit demi sedikit runtuh. Namun, tetap saja untuk mencapai kelas menengah terhambat bagi bangsa Indonesia. Karena orang Tionghoa telah memperoleh landasan kuat menggunakan hubungan mereka dengan kelompoknya sendiri, pemilikan kapital yang lebih besar, serta pengetahuan lebih terkait dunia luar (Purnawan Basundoro, 2013: 72).

Terutama pada masa krisis tahun 1930an, di Indonesia berlangsung lebih lama dibadingkan dengan negara lain (Purnawan Basundoro, 2013: 78). Kesulitan besar terjadi pada Perusahaan barat dan petani Indonesia. Ribuan kuli banyak yang dipecat, dari Deli kembali ke Jawa. Dalam kondisi tersebut, banyak penganggur meninggalkan kota-kota di Jawa dan kembali ke desa yang ditinggalkannya. Kemungkinan dari mereka kembali pada metode lama dengan ekonomi tertutup dan pertanian subsisten pada lahan milik mereka sendiri. Namun, bagi mereka yang tidak memiliki lahan hal tersebut menjadi beban di pedesaan. Akhirnya, terjadi penumpukkan penganggur di wilayah pedesaan.

Kondisi semakin diperparah pada masa pendudukan Jepang dan sebelum kemerdekaan. Periode pendudukan Jepang merupakan periode kekerasan. Berbagai bidang mengalami kemunduran, khususnya ekonomi (W.F. Wertheim, 1999: 90). Meskipun banyak petani yang dipermiskin dibandingkan dengan masa sebelum kedatangan Belanda di Indonesia. Namun, menurut Wertheim kesehatan ekonomi Indonesia bergantung pada kekuatan perusahaan-perusahaan asing (perkebunan dan pertambangan). Sehingga pada periode ini, tidak ada pengaruh baik yang diberikan Jepang terhadap perekonomian bangsa, khususnya petani di desa.

Puncak dari berbagai kesulitan itu tampak lebih jelas di awal kemerdekaan Indonesia. Batas wilayah desa-kota yang sudah terbentuk sebelum kedatangan Belanda, ambruk pada periode ini. Banyak penduduk miskin pedesaan yang berbondong-bondong bermigrasi ke kota. Alasannya ialah kesulitan lapangan pekerjaan pada periode sebelumnya dan hal itu berlangsung hingga kemerdekaan, khususnya bagi masyarakat yang tidak memiliki lahan di desa. Sedangkan, kesempatan kerja bagi buruh tani ditentukan oleh siklus pertanian di desa. Sampai tahun 1970an masa tanam hanya satu kali setahun (Jan breman, 1995: 15).

Untuk mendapatkan kepastian guna memenuhi kebutuhan sehari-hari. Kota sebagai harapan tumpuan mecari pekerjaan, menyebabkan siklus migrasi terulang kembali. Yaitu berpindahnya manusia ke wilayah perkotaan. Bahkan sejak tahun 1950an hingga 1970an tren penduduk urban terus meningkat. Tren tersebut ditunjukkan melalui tabel dibawah ini; 


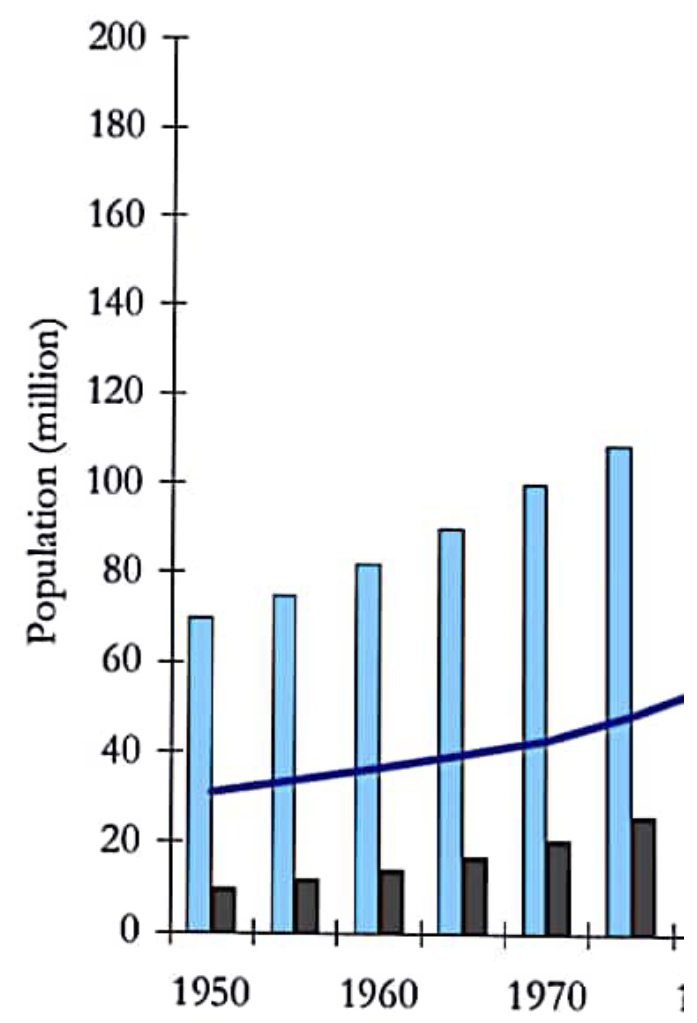

Figur 1. Tren Penduduk Urban dan Rural di Indonesia. Sumber: www.dsfindonesia.org².

Secara nasional sebuah data populasi berdasarkan kriteria BPS (Badan Pusat Statistik) menunjukkan tren jumlah penduduk tinggal di kota dan pedesaan berdasarkan grafik 1.1, didominasi oleh penduduk yang tinggal di kota. Tabel berwarna biru merupakan gambaran kisaran jumlah penduduk yang tinggal di perkotaan Indonesia dan tabel berwarna hitam, merupakan penduduk pedesaan.

Sejak tahun 1950 jumlah penduduk yang tinggal di kota dan mereka yang berada di pedesaan, jika dibandingkan jumlahnya hampir tiga kali lipat lebih menjadi penghuni kota. Hal itu juga didukung oleh pertumbuhan penduduk Indonesia. Purnawan Basundoro dalam bukunya yang berjudul Minyak Bumi dalam Dinamika Politik dan Ekonomi Indonesia 1950-1960an, bahwa selama kemerdekaan terjadi peningkatan pertumbuhan sebesar 2,2\% per tahunnya (Purnawan Basundoro, 2012: 84).

\section{Deindustrialisasi Pedesaan: Studi Kasus Yogyakarta}

Industrialisasi merupakan proses transformasi masyarakat akibat keberadaan industri sehingga mata pencaharian penduduk terikat dalam bidang

2) Assistance Team on Fiscal Decentralization for the Minister of Finance, Republik of Indonesia. "Indonesia's Intergovernmental Transfer: Response on Future Demographic and Urbanization Shifts", dalam https://www.dsfindonesia.org . Diakses pada 1 Maret 2018, Pukul. 08:09 WIB. 
industri (Vivin Retno Damayanti, 2008: 68) . Sejak abad ke-19, desa-desa Indonesia khususnya di Jawa telah mengalami perubahan yang signifikan akibat masuknya sistem perekonomian baru ke pedesaan, yakni kapitalisme perkebunan. Dua kebutuhan utama dari sistem kapitalisme perkebunan ini adalah lahan dan tenaga kerja. Yogyakarta yang merupakan bagian dari wilayah Vorstenlanden merupakan pusat industri gula, tembakau dan pertambangan yang berada dalam kuasa modal asing. Pada masa Revolusi Kemerdekaan, pabrik-pabrik milik Belanda itu hancur lebur dan tidak bisa dibangun kembali. Keadaan ini mengakibatkan adanya pengangguran yang tidak sedikit jumlahnya. Hal ini terjadi lantaran sebagian besar petani di Yogyakarta adalah buruh tani, saat pabrik Belanda belum dihancurkan, pekerjaan menjadi buruh tani adalah salah satu pilihan pekerjaan yang cukup mendatangkan penghasilan bagi masyarakat Yogyakarta (D. W. Fryer, 1959: 458).

Sedangkan mayoritas petani Yogyakarta tidak memiliki tanah garapan. Memasuki tahun 1950an, ketika perang kemerdekaan berakhir, mereka terpaksa mencari pekerjaan ke lain desa atau bahkan ke kota. Sehingga dapat diketahui bahwa di desa-desa sedang kekurangan pekerjaan yang akhirnya memaksa penduduk yang terbiasa bertani untuk mencari pekerjaan di kota (Rika Inggit Ismawati, 2015: 54).

Namun hal baiknya, setelah melewati masa Jepang dan juga serangkaian perang pada masa Revolusi, terjadi perubahan stratifikasi sosial di Indonesia. Bangsa kulit putih yang pada masa kolonial merupakan lapisan kelas atas kini telah menjadi golongan pariah (Rika Inggit Ismawati, 2015: 61). Kemerdekaan membuat mereka yang dulunya berada di lapisan kelas paling bawah-kini menjadi lapisan kelas paling atas (W.F Wertheim, 1999:68). Buruh tani desa di sekeliling Yogyakarta sulit mendapatkan pekerjaan di desa. Mereka memilih untuk merantau ke kota. Proses ini secara langsng diakibatkan oleh deindustrialisasi yang terjadi di pedesaan, yaitu proses yang terjadi akibat pengaruh keberadaan industri. Dalam tahap ini, transformasi justru dari masyarakat industrial ke pertanian. Dikutip dalam Purnawan Basundoro, seorang sosiolog bernama Schneider, menyebutnya menjadi "kota mati" yang mana mata pencaharian baru harus dicari (Purnawan Basundoro, 2013).

\section{Mata Pencaharian Baru dan Berkembangnya Sektor Informal Perkotaan}

Setelah kemerdekaan hal signifikan yang terjadi ialah membludaknya masyarakat desa untuk berbondong-bondong bermigrasi ke kota. Urbanisasi semakin mengarah pada suatu pola produksi dan konsumsi kapitalistik yang seragam (Terry McGee, 1997: 7). Istilah ini menandakan suatu upaya untuk merevisi pandangan urbanisasi konvensional atau Eurosentris, sebagai suatu proses yang mengasumsikan perbedaan antara pedesaan dan 
perkotaan (Abidin Kusno, 2010: 3.). Menurut McGee sejak kemerdekaan tidak ada keterpisahan antara desa dan kota. Melainkan desa-kota dalam hal ini membentuk satu kesatuan hubungan yang terjalin. Karena akan sulit membedakan batasan-batasan antar ruang secara spasial. Manakah yang layak disebut "kota", "pinggiran kota", atau "pedesaan" (Arie Setyaningrum Pamungkas, 2016: 1-5.). Namun perlu digaris bawahi, bahwa hubungan antar ruang tersebut salah satunya terjalin oleh migrasi sirkuler yang terjadi secara berlebihan. Sehingga ketika mobilitas terjadi, hubungan-hubungan sosial yang tercipta dari tempat mereka tinggal pun terbawa ke tempat mereka berpindah (kota). Istilah tersebut dipahami oleh McGee sebagai fenomena terbentuknya desakota.

Dorongan bermigrasi dalam konteks ini lebih mengarah pada akibat menumpuknya para penganggur di desa. Jumlah pengangguran yang membludak merupakan akibat dari politik bumi hangus. Sebelumnya sudah dijelaskan, bahwa awal abad ke-20, 17 pabrik gula mempekerjakan banyak petani lokal dan migran sebagai pekerja yang dibayar. Lebih dari 15.000 orang terlibat sebagai tenaga kerja permanen maupun musiman (Bambang Purwanto, 2015: 29). Sebagian besar dari mereka ialah orang-orang yang tidak memiliki tanah pertanian di pedesaan.

Posisi dilematis, disisi lain kemerdekaan menghapuskan segregasi ras yang terbentuk sebelumnya, namun mereka harus kehilangan pekerjaan di desa. Akhirnya, demi untuk menyambung hidup mau tidak mau mereka harus menyiasati untuk mendapatkan pekerjaan sesuai dengan kualitas diri. Karena sebagian dari mereka berpendidikan rendah. Untuk itu jika di desa tidak ada lapangan pekerjaan, terpaksa mereka harus ke kota untuk mencari mata pencaharian baru. Diantara beberapa pekerjaan yang ditawarkan di Kota Yogyakarta, sektor informal tukang becak merupakan sebuah peluang menjanjikan bagi para pencari kerja. ${ }^{3}$ Pada tahun 1950an1970an perkembangan Kota Yogyakarta sebagai kota yang berukuran sedang, serta semakin meningkatnya sarana pendidikan, perkantoran, dan pusat perbelanjaan, khususnya pasar tradisional membutuhkan transportasi penunjang (Sartono Kartodirdjo, 1981: vii).

3) Keberadaan sektor informal sebenarnya dapat mengatasi masalah ketenagakerjaan di kota, karena dapat menampung golongan masyarakat yang tidak terserap bekerja di sektor formal. Sedangkan pengertian dari sektor informal ialah sektor yang tidak terorganisasi (unorganized), tidak teratur (unregulated), dan mayoritas dari mereka legal tetapi tidak terdaftar (unregistered). Sektor informal memiliki karakteristik seperti jumlah unit usaha yang banyak dalam skala kecil, kepemilikan oleh individu atau keluarga, teknologi yang sederhana dan padat tenaga kerja, tingkat pendidikan dan keterampilan yang rendah, tingkat upah yang juga relatif rendah dibandingkan sektor formal. Kebanyakan pekerja di sektor informal perkotaan merupakan migran dari desa atau daerah lain. Motivasi internal pekerja biasanya bertujuan untuk memperoleh pendapatan yang cukup untuk sekedar mempertahankan hidup (survival). Sektor ini memberikan kemungkinan kepada tenaga kerja yang berlebih di pedesaan untuk bermigrasi dari kemiskinan dan pengangguran. 
Sartono Kartodirdjo mengungkapkan pada periode tersebut, becak merupakan transportasi yang mampu dijadikan sarana penghubung, yang bersifat fleksibel (Sartono Kartodirdjo, 1981: vii). Gedung yang berdekatan dan sarana-prasarana di Kota Yogyakarta dengan jarak yang tidak terlalu jauh, tidak membutuhkan transportasi cepat. Selain berbagai alasan yang sudah disebutkan, berikut beberapa faktor lain yang diungkapkan Sartono terkait kepopuleran becak di Kota Yogyakarta waktu itu;

Becak menyediakan servis dari pintu ke pintu, dapat membawa dua atau tiga orang, barang dan juga koper.

1. Memiliki bentuk atau konstruksi yang sederhana dan pengoperasiannya mudah.

2. Karena mengemudi becak tidak memerlukan keahlian khusus atau pengetahuan teknis, sistem transportasi becak memberikan kesempatan kerja yang besar bagi sejumlah pekerja tidak terampil yang datang sebagai migran dari pedesaan.

3. Di sebagian besar Kota Indonesia sistem transportasi becak masih sesuai dengan sistem transportasi kota secara umum (Sartono Kartodirdjo, 1981: vii).

Wajar saja dari beberapa pekerjaan yang ditawarkan, banyak para pencari kerja lebih memilih membecak. Perannya yang substansial di kota, tentunya akan memberikan banyak keuntungan bagi pengayuhnya. Selain diminati karena memang pekerjaan itu tidak membutuhkan keahlian khusus. Namun juga, ada indikasi bahwa pada periode sebelumnya kota terlebih dulu yang membutuhkan transportasi becak.

\section{Becak dalam Arus Perkembangan Kota}

Becak dalam kamus bahasa Indonesia tahun 1940an merupakan sebuah alat transportasi umum untuk kelas menengah ke bawah penduduk kota di Indonesia (Erwiza Erman, 2013: 388). Kendaraan becak membanjiri terjadi di berbagai kota besar di Indonesia setelah kemerdekaan (Erwiza Erman, 2013: 389). Kata becak itu sendiri berasal dari bahasa Hokkien (Lusiana Lubis, 2012: 290) ${ }^{4}$ : be chia (Judisseno Rimsky, 2017: 244). Arti dari dua kata tersebut, be adalah kaki, dan chia ${ }^{5}$ adalah transportasi. Dilihat dari sejarahnya, becak pertama kali ditemukan di Jepang pada tahun 1869 dan kemudian menjadi transportasi modern di akhir abad ke-19 dan awal abad ke-20 di seluruh

4) Bahasa Hokkien merupakan bahasa yang digunakan untuk berkomunikasi sesama etnik Tionghoa, selain menggunakan bahasa Mandarin.

5) Kata becak berasal dari bahasa Cina; terdiri dari dua kata be adalah kaki dan tjia adalah transportasi. Dalam Erwiza Erman "Kehidupan dan Politik Pengayuh Becak di Jakarta (1930-1960)" Jika dalam tulisan sebelumnya di atas chia sebagai sebutan transportasi. Pemilihan kata chia berdasarkan sumber terbaru yang ditemukan penulis yaitu dalam buku ktivitas dan Kompleksitas Kepariwisataan: Suatu Tinjauan tentang Kebijakan Pengembangan Kepariwisataan karya Rimsky K.Judisseno. 
Asia (Petrik Matanasi, 2018). Bentuk awalnya sangat sederhana, yakni sebuah kendaraan yang ditarik orang di depan. Pelan-pelan becak mengalami kemajuan dalam hal teknologinya. Becak tidak lagi ditarik dari depan, akan tetapi dijalankan atau dikayuh dengan kaki oleh pengayuhnya dari bagian belakang.

Tidak diketahui kapan persisnya becak masuk ke Indonesia. Walaupun demikian, becak yang ditarik orang tentunya sudah ada bersamaan dengan kehadiran orang-orang Cina di kota-kota Indonesia, seperti Medan, Batavia atau Jakarta, Surabaya dan Makassar (Petrik Matanasi, 2018). Berbeda dengan Warren, menurut pemberitaan Jawa Shinbun, 20 Januari 1943, becak justru diperkenalkan dari Makassar ke Jakarta pada akhir tahun 1930an (Petrik Matanasi, 2018).

Di Surabaya sebagaimana dijelaskan sebelumnya, becak yang ditarik manusia itu, disebut angkong (Jay Akbar, 2018). Angkong ini sudah ada sebelum tahun 1900, di mana pemilik dan pengayuhnya umumnya dari suku Hok Cia. Di Kota Medan, becak yang ditarik orang ini sudah muncul seiring dengan kedatangan-kedatangan orang-orang Cina baik sebagai buruh di perkebunan-perkebunan tembakau maupun sebagai pedagang di Kota Medan. Erwiza mengungkapkan bahwa becak beroda tiga sudah di impor ke Indonesia sejak tahun 1930an. Di Jakarta misalnya, studi Abeyasekere mengenai Jakarta, sekitar masa Depresi Ekonomi dunia 1930an, bahwa sudah ada sekitar 100 becak. Kemudian pada tahun 1936, menurut hasil penelitiannya, kendaraan beroda tiga ini sudah banyak digunakan di Batavia menjelang akhir pemerintahan kolonial.

\section{Popularitas Becak di Yogyakarta Sebelum Kemunculan Motor Dua Tak}

Periode Pendudukan Jepang (1942-1945) telah menghancurkan berbagai alat transportasi umum dan membawa kesulitan memperoleh bahan bakar dan spare parts kendaraan. Kondisi ini telah menyebabkan kendaraan seperti sepeda menjadi alat transportasi pribadi dan becak dan dokar menjadi alat transportasi publik yang semakin dibutuhkan. Kelangkaan bahan bakar pada zaman pendudukan Jepang dan setelahnya di Indonesia menjadikan transportasi tidak bermotor semacam andong dan becak berperan penting. Harga jasa transportasi becak lebih terjangkau dibanding andong sehingga menjadikan moda transportasi ini lebih populer di masa ini dan setelahnya. Namun, moda transportasi becak memiliki kelemahan, karena mesin penggeraknya adalah manusia, tentunya jarak yang ditempuh pun terbatas. Penelitian yang dilakukan oleh Sartono Kartodirdjo, mengungkapkan bahwa 47,2\% pengemudi becak hanya mampu mengayuh sekitar 4-6 km dalam sekali angkut (Sartono Kartodirdjo, 1981: 116). Jika dirata-rata perjalanan tersebut membutuhkan waktu antara 30-60 menit (Sartono Kartodirdjo, 1981: 116). 
Yogyakarta sebagai kota yang berukuran sedang, bergantung pada becak sebagai sarana mobilitas penduduk dan barang untuk transportasi jarak dekat dan menengah (Sartono Kartodirdjo, 1981: 1).

Pada tahun 1950-1960an, peran becak sudah terintegrasi dengan kebutuhan transportasi umum perkotaan. Beberapa segi kehidupan sosialekonomi masyarakat Yogyakarta di awal kemerdekaan yang baru dibangun kembali, membutuhkan becak sebagai kendaraan dengan harga terjangkau. Pelanggan utama becak ialah para pedagang sayur serta pelajar.

Pada tahun 1960-1970an, stabilitas ekonomi yang mulai membaik berakibat pada perkembangan pesat kota. Konsentrasi dari beberapa fungsi komersial di pusat kota secara terus-menerus, telah memunculkan fungsi lain. Malioboro selain menjadi distrik perekonomian yang dipenuhi oleh becak, pertokoan, industri kecil, hotel, serta pusat perbelanjaan. Pada periode ini mulai dikenal dipelosok negeri sebagai salah satu tempat rekreasi bagi wisatawan lokal maupun luar daerah. Sedangkan becak selain menjadi transportasi penunjangnya, ia juga mulai berperan sebagai ikon wisata.

Perubahan paling signifikan terjadi sekitar tahun 1970an, tepatnya 1975, dominasi berbagai merk kendaraan bermotor dua "tak" dan kendaraan mobil pribadi, dibeberapa sisi menggeser peran becak sebagai transportasi. Mobil bak murah mulai menyediakan jasa yang lebih murah dari Beberapa pelanggan dari kalangan para pemuda yang menempuh pendidikan mulai beralih pada kendaraan mesin, selain lebih cepat, juga secara sosial hal itu dipandang sebagai sesuatu yang mengesankan. Meskipun, disisi lain becak tetap eksis, sebagai ikon wisata Kota Yogyakarta bahkan berlangsung hingga sekarang.

Dari berbagai paparan sebelumnya secara garis besar becak memiliki peran yang sangat sentral di Kota Yogyakarta periode 1950an hingga 1970an. Namun, tidak lengkap rasanya pembahasan kendaraan becak tanpa ulasan

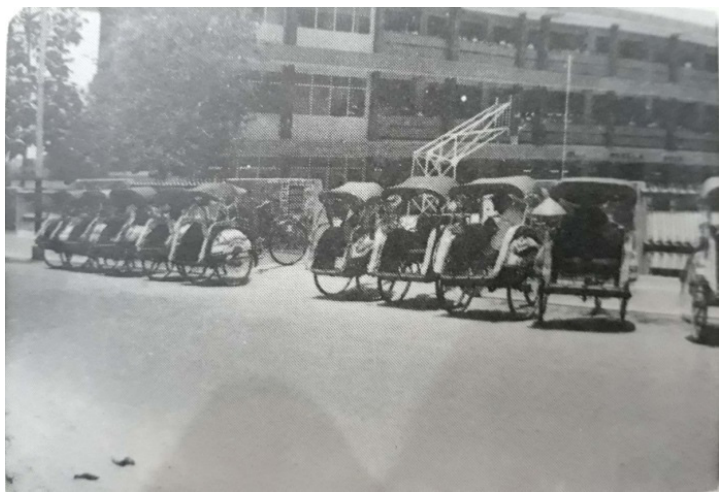

Figur 2. Becak mangkal didepan sekolah tahun 1950an. Sumber: Sartono Kartodirjo. The Pedicab in Yogyakarta

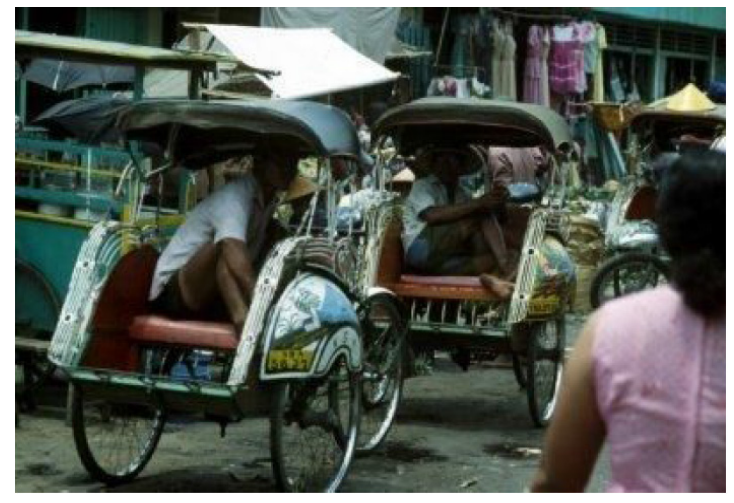

Figur 3. Tukang Becak dan becaknya di Pasar Beringharjo tahun 1975. Sumber: KITLV Digital Media Library - Rij wachtende betjak in een winkelstraat te Yogyakarta. 
manusia pengayuhnya, yang merupakan mesin penggerak. Karena tanpa keberadaan pengayuh becak, kendaraan tersebut hanya seonggok "kursi beroda” tentunya. Oleh karena itu, dalam bab selanjutnya akan dipaparkan terkait bagaimana kota itu dijalankan melalui sudut pandang para pengayuh becak.

\section{Etnografi Ruang Kota dari Pelaku Kelas Bawah}

Ini adalah bagian kedua dari artikel yang bertujuan mengeksplorasi hubungan manusia ke dalam narasi sejarah kota. Henry Levebvre seorang sosiolog Prancis melalui teorinya tentang produksi ruang, mengungkapkan bahwa untuk menganalisis sejarah kota, maka harus memahami hubungan atau interaksi penghuninya (Arie Setyaningrum Pamungkas, 2019: 2). Dalam hal ini, ruang-ruang kota tahun 1950an hingga 1970an tidak bisa sepenuhnya dipahami tanpa memasukkan konteks hubungan sosial. Hubungan tersebut bersifat relevan. Karena pada periode ini, ruang-ruang kota di mediasi oleh becak sebagai efek dari kondisi sosial, politik, dan ekonomi, yang menempatkannya sebagai moda transportasi utama.

Di level lain, kota merupakan ruang yang "dialami" oleh penghuninya. Sifat experiential memaksa kita harus melihat dengan sudut pandang orangorang yang mengalami. Cara mengangkat perspektif subaltern ini adalah melalui cerita pribadi tukang becak. Pasca kemerdekaan, kota-kota Indonesia dihuni oleh beragam manusia termasuk kelompok menengah ke bawah, salah satunya tukang becak. Jika kita menonton film-film dokumenter tahun 1950an, utamanya tahun 1970an, kita akan menjumpai scene tukang becak yang muncul berkali-kali di jalanan kota. ${ }^{6}$ Berbeda sekali dengan Kota Indonesia saat ini, yang dipenuhi oleh lalu-lalang kendaraan bermotor. Oleh karenanya, diperlukan cara yang berbeda pula untuk memahami kota periode tersebut.

Melalui beberapa pemaparan pada paragraf sebelumnya di atas, pertanyaan besar yang ingin dijawab dalam diskusi ini ialah, bagaimana orang-orang tersebut menjalankan kehidupannya di kota? Bagaimana mereka mengalami kota pada periode ini? (Erwiza Erman, 2011). ${ }^{7}$ Karena kota sebagai fenomena sosial tentunya membentuk pengalaman yang berbeda di tiap kalangan. Pertanyaan-pertanyaan seperti itu akan sulit terjawab jika

6) Beberapa film dokumenter tentang suasana perkotaan Indonesia tahun 1950an hingga 1970an dapat dilihat di Youtube. Beberapa film tersebut, contohnya; Wet Earth and Warm People (Jakarta 1970), Jakarta in 1965, Dokumentasi Suasana Jakarta 1970, Indonesia Yogyakarta 1972.

7) Erwiza pernah memberikan kritik terhadap perkembangan sejarah lisan di Indonesia. Bahwa pertanyaan-pertanyaan tersebut, seharusnya mulai diangkat. Hubunganhubungan (tukang becak) yang dibangun di jalanan, termasuk pengalaman, sikap, dan pandangan kelompok kelas bawah. Lihat; Erwiza Erman. Penggunaan Sejarah Lisan dalam Historiografi Indonesia. Jurnal Masyarakat \& Budaya, Nomor 1, Volume 13, Tahun 2011. 
hanya mengandalkan sumber tertulis atau dokumen. Untuk itu, digunakan sejarah lisan sebagai pendekatan pokok untuk mendapatkan informasi yang tidak terkandung dalam berbagai sumber tertulis. Paul Thompson dalam bukunya The Voice of The Past, mengutarakan bahwa melalui sejarah lisan, memungkinkan munculnya sosok-sosok pahlawan tidak saja dari kalangan pemimpin terkemuka, melainkan juga dari rakyat kebanyakan yang tidak dikenal (Paul Thompson, 1978:1-18). Secara tidak langsung, pendekatan ini mampu memberikan panggung kepada manusia-manusia dari berbagai level.

Sehingga apa yang dimaksudkan Eric Wolf, kaum marjinal termasuk tukang becak sebagai manusia tanpa sejarah atau yang ia sebut, "people without history" (Eric R. Wolf, 1982:47) beralih menjadi "people with history". Lalu, mengapa diskusi semacam ini perlu diangkat ruang? Thompson menjawabnya dengan alasan, bahwa setiap kehidupan itu menarik. Sedangkan kehadiran tukang becak meskipun dianggap sebagai kaum marjinal, periode 1950an hingga 1970an mereka juga memiliki peran sentral terhadap kondisi kota.

\section{Tukang Becak, Hubungan Sosial \& Kota}

Sebelum memasuki pembahasan kota secara menyeluruh, telah dirangkum beberapa pola umum yang diangkat melalui cerita kehidupan sehari-hari beberapa tukang becak sebagai berikut; Pertama, tekanan untuk menjajaki kota berawal dari kehidupan keluarga. Latar belakang orang tua yang mayoritas bekerja sebagai buruh tani, sehingga tidak mampu menyekolahkan anakanaknya. Hal tersebut berimbas pada minimnya keterampilan dan didukung pula dengan tidak adanya lapangan pekerjaan yang memadai di desa. Faktor tersebut pun menjadi salah satu faktor pendorong bermigrasinya para tukang becak ke kota.

Sedangkan salah satu faktor penarik dari kota ialah sebuah "imajinasi" kesempatan kerja yang berlimpah. Argumen sebelumnya di atas dapat dibuktikan, melalui beberapa kasus yang secara langsung penulis dapatkan melalui wawancara dengan para tukang becak di Yogyakarta. Namun sebelum masuk pada pembahasan, terlebih dahulu penulis memperkenalkan para tukang becak tersebut, sebagai berikut; Tahun 1950an Panut seorang tukang becak dari Wates, Yogyakarta berasal dari keluarga buruh tani, lebih tepatnya buruh $n g a r i t^{8}$. Sedangkan penghasilan dari menjadi buruh di desa hanya cukup untuk memenuhi kebutuhan makan sehari-hari. Sehingga ia pun memutuskan untuk merantau ke kota mengais rezeki. Melalui seorang temannya, akhirnya ia diajak untuk menarik becak.

Motivasi yang berkaitan dengan paragraf sebelumnya, dialami oleh Poniman seorang migran yang berasal dari Wonogiri (Wawancara Poniman,

8) Ngarit merupakan kata dalam bahasa jawa yang berarti mencari rumput untuk makan ternak. Biasanya ternaknya berupa hewan sapi, kerbau, kambing, dan kelinci. Sedangkan alat yang digunakan adalah arit atau parang, sabit dan sejenisnya. 


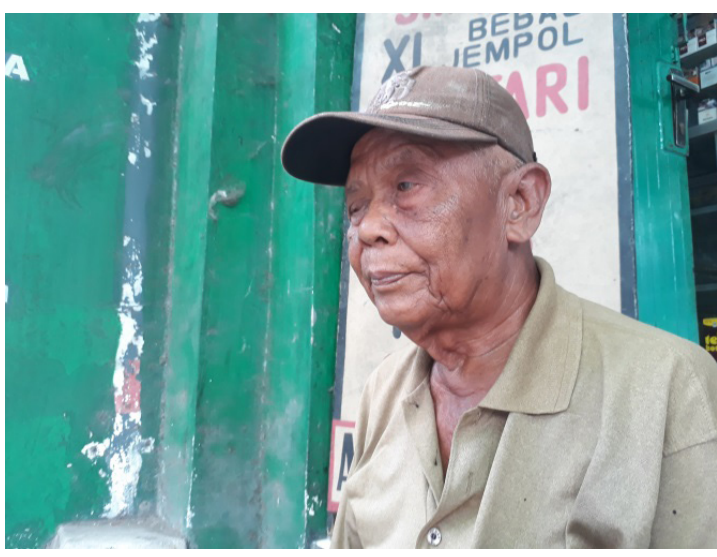

Figur 4. Tukang Becak Panut saat diwawancarai. Sumber: Secara langsung diabadikan oleh penulis.

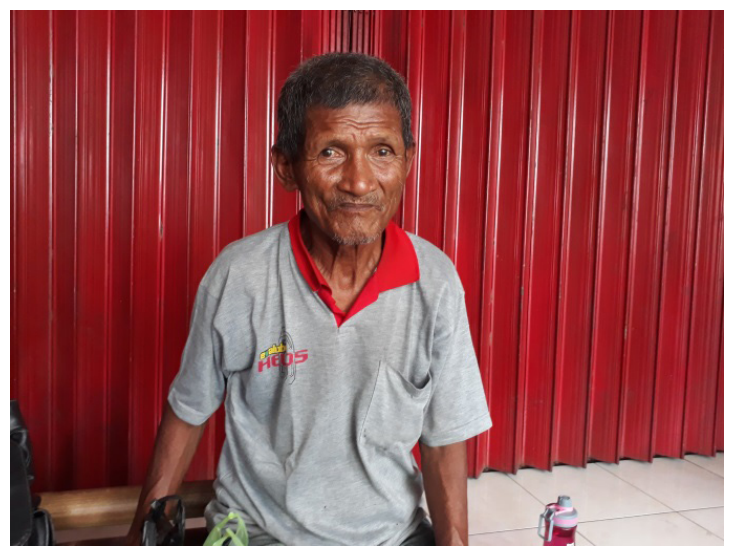

Figur 5. Tukang Becak Poniman saat diwawancarai. Sumber: Secara langsung diabadikan oleh penulis.

15 September 2018). Ia menjadi tukang becak di Yogyakarta sejak tahun 1963. Lahir sebagai anak pertama dari orang tua yang bekerja sebagai buruh tani. Namun di tahun itu pula, Poniman harus kehilangan kedua orang tuanya. Ditambah orang tua yang tidak memiliki tanah garapan di desa, sedangkan ia memiliki seorang adik perempuan yang harus dinafkahi. Akhirnya ia pun memutuskan untuk merantau ke kota menjadi tukang becak (Wawancara Panut, 28 September 2018).

Pada 1966 Mardi, tukang becak yang hanya lulusan Sekolah Dasar, berasal dari Cawas, Klaten (Wawancara Mardi, 14 September 2018) bersama dengan Sugiono (Wawancara Sugiono, 15 September 2018) tukang becak tahun 1967 dari Sawit, Sewon Bantul. Kedua orang tua mereka merupakan buruh tani, yang tidak memiliki ladang. Sedangkan, ibu dari Sugiono membuat tempe untuk dijajakan di Pasar Beringharjo. Bahkan sebelum menjadi tukang becak, mereka sempat menjadi buruh tani di desanya. Namun karena pernikahan, maka mereka memutuskan untuk merantau dengan alasan menjadi buruh tani tidak bisa diandalkan. Sedangkan, memiliki istri berarti harus menafkahi anak orang. Lalu, melalui ajakan teman mereka, akhirnya merantau ke kota untuk menjadi tukang becak.

Secara berurutan tahun 1968, 1969, 1970, dan 1971 tukang becak dari pinggiran Kota Yogyakarta, yaitu dari wilayah pedesaan Kabupaten Bantul, dengan latar belakang pekerjaan orang tua yang sama, yaitu bekerja sebagai buruh. Mereka secara berurutan bernama, Suripto (Wawancara Suripto, 16 September 2018), Prapto Utomo (Wawancara Prapto Utomo, 14 September 2018), Sugiwanto (Wawancara Sugiwanto, 19 September 2018), dan Slamet (Wawancara Slamet, 29 September 2018). Terdapat perbedaan dengan Sugiwanto, orang tuanya memang seorang buruh, namun buruh batik. Sedangkan orang tua yang lainnya merupakan buruh tani penggarap sawah juragan di desanya. Oleh karena itu, mereka berempat berpendidikan rendah, 


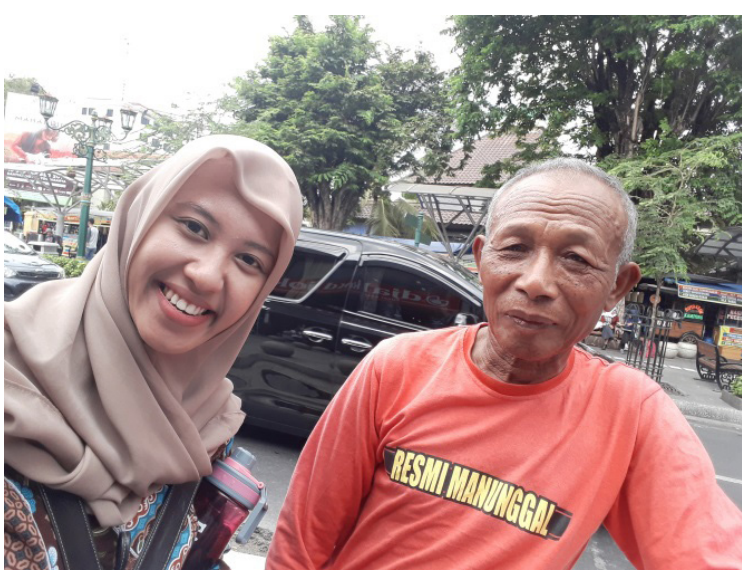

Figur 6. Tukang Becak Mardi saat diwawancarai bersama penulis Sumber: Secara langsung diabadikan oleh penulis.

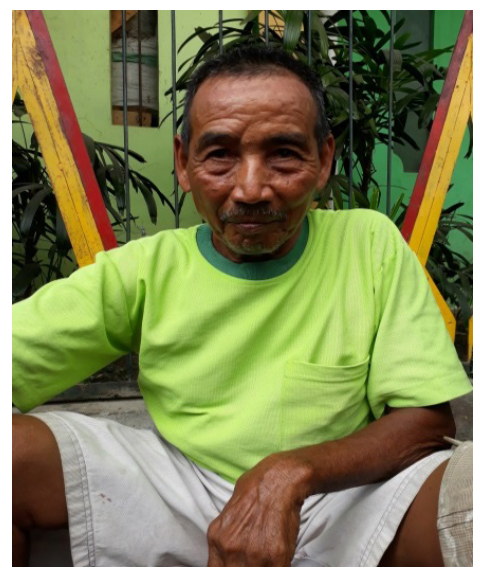

Figur 7. Tukang Becak Sugiono saat diwawancarai. Sumber: Secara langsung diabadikan oleh penulis.

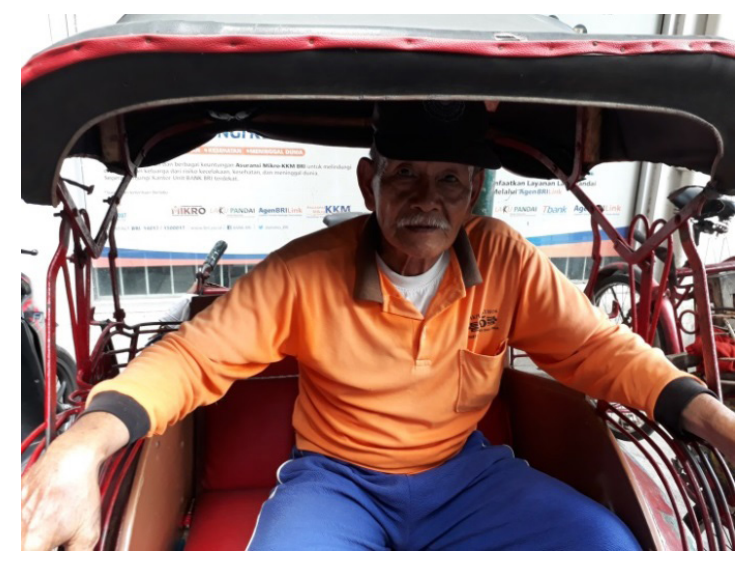

Figur 8. Tukang Becak Suripto saat diwawancarai. Sumber: Secara langsung diabadikan oleh Penulis.

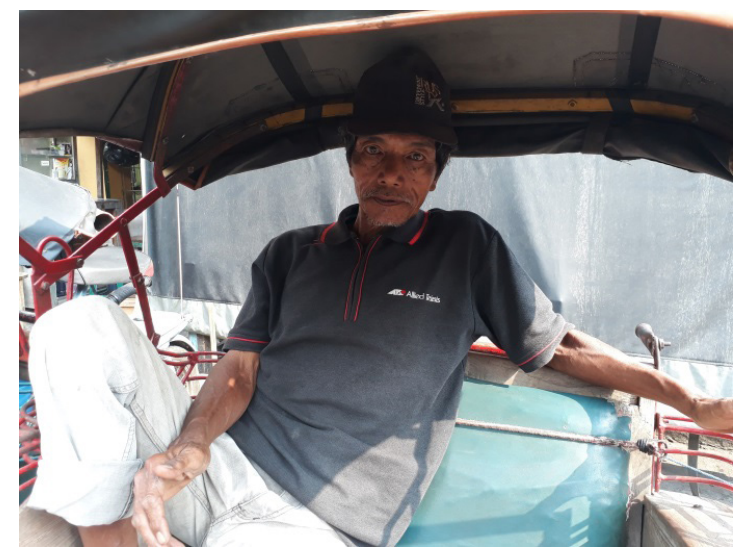

Figur 10. Tukang Becak Sugiwanto saat diwawancarai. Sumber: Secara langsung diabadikan oleh penulis.

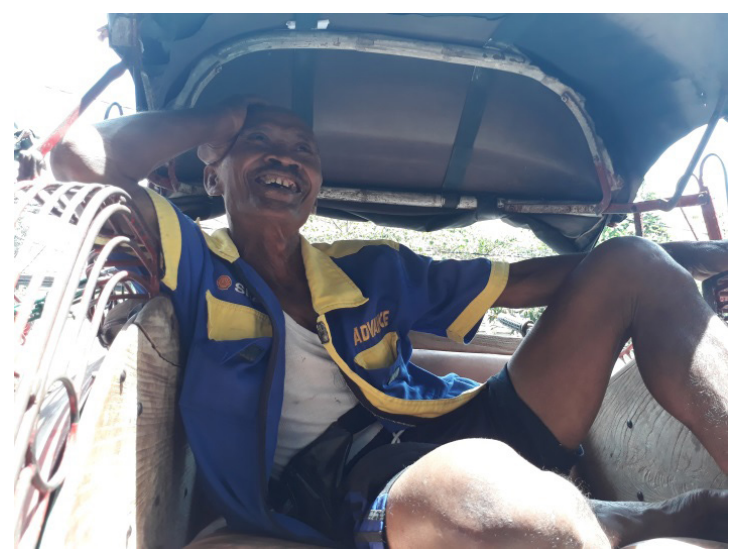

Figur 9. Tukang Becak Prapto Utomo saat diwawancarai. Sumber: Secara langsung diabadikan oleh penulis.

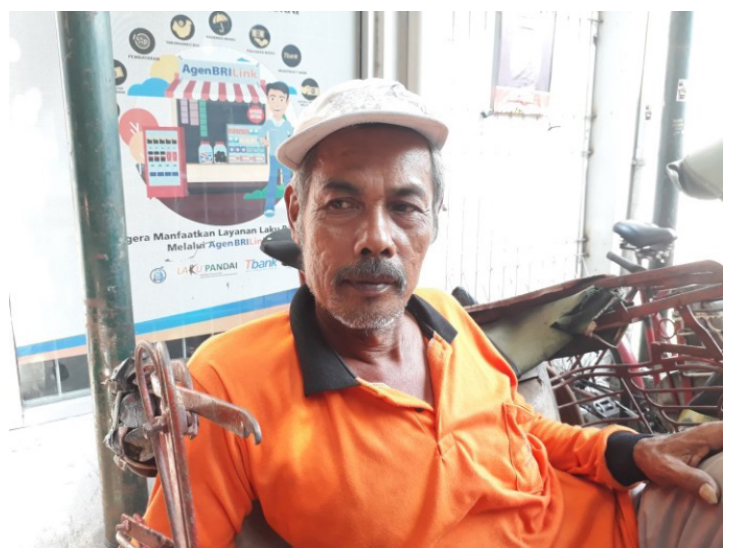

Figur 11. Tukang Becak Slamet saat diwawancarai Sumber: Secara langsung diabadikan oleh penulis. 
SD pun tidak lulus. Karena orang tua tidak mampu membiayai, bekerja sebagai buruh hanya cukup untuk makan sehari-hari saja.

Cerita lainnya dari Agus Ponimin yang sudah membecak sejak 1972. Ia mengaku menjadi tukang becak karena belum memiliki pekerjaan (Wawancara Agus Ponimin, 29 September 2018). Sedangkan, ia tidak mengenyam bangku pendidikan karena orang tua tidak mampu menyekolahkan. Kasus yang sama dengan kisah sebelumnya, orang tua hanya buruh tani, sedangkan tahun itu ia memutuskan untuk menikah. Semakin kompleksnya tuntutan kebutuhan rumah tangga yang akhirnya mendorong Agus Ponimin menjadi tukang becak sampai sekarang.

Kasus yang terakhir, cerita dari Mardiyanto tukang becak Pasar Kranggan yang berasal dari Bantul (Wawancara Mardiyanto, 28 September 2018). Mengaku tidak pernah mengenyam bangku pendidikan, dan orang tua hanya buruh tani, membuatnya memilih merantau menjadi tukang becak. Pernikahan yang berlangsung pada 1973, memaksa dia untuk menghasilkan uang setiap hari. Sebelumnya ia sering ikut orang tuanya ke sawah untuk menjadi buruh. Namun pekerjaan sebagai buruh menurutnya tidak memberi kepastian.

Pola yang mayoritas sama, terlahir di keluarga miskin (pekerjaan orang tua sebagai buruh), berimbas pada latar belakang pendidikan yang rendah. Sedangkan menurutnya, menjadi tukang becak mampu mengusahakan pemasukan tiap harinya. Karena sebelum menikah, ia harus bertanggung jawab pula membantu merawat ketujuh adiknya. Hingga akhirnya, ia pun memilih menjadi tukang becak hingga sekarang.

Disisi lain, dalam sebuah pidatonya Presiden Sukarno pernah mengungkapkan "jangan menjadi tukang becak! Paling tidak menjadi seorang

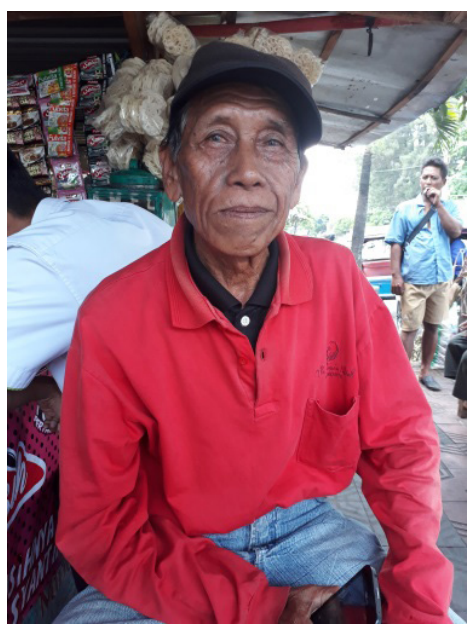

Figur 12. Tukang Becak Agus Ponimin saat diwawancarai. Sumber: Secara langsung diabadikan oleh penulis.

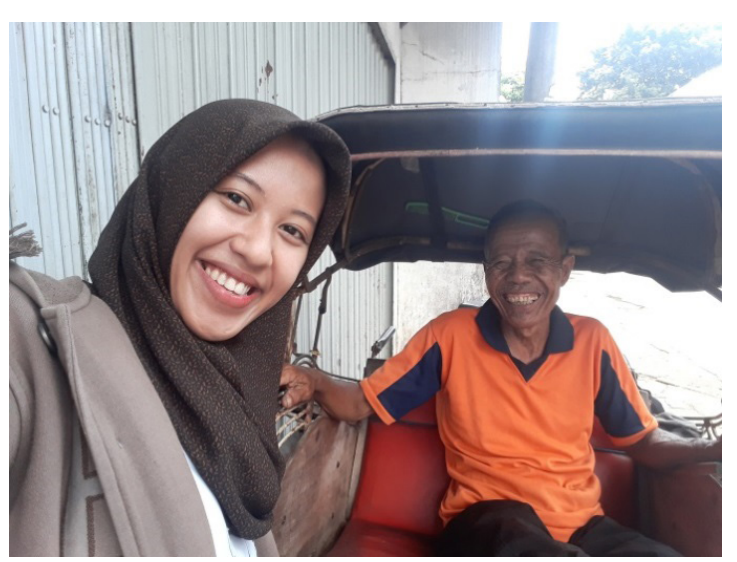

Figur 13. Tukang Becak Mardiyanto bersama penulis saat diwawancarai. Sumber: Diabadikan secara langsung oleh penulis. 
kuli, karena menarik becak adalah pekerjaan tidak bermartabat." Menghela becak dilihat sebagai pekerjaan buntu bagi laki-laki setara prostitusi bagi perempuan di Indonesia (Lea Jellinek,1987:184). Namun, seperti kalimat yang diucapkan oleh Suripto dibawah ini, jikalau ia dilahirkan dari keluarga yang mapan, ia pun sebenarnya tidak ingin menjadi tukang becak.

"Tak ada orang yang bercita-cita menjadi miskin, namun jika sudah miskin harus bagaimana lagi? Saya percaya menjadi tukang becak itu takdir dari Tuhan...." Ungkap Suripto.

Berangkat dari poin yang diungkapkan tukang becak sebelumnya, pada tahun 1950an hingga 1970an becak yang digerakkan oleh kaki manusia membentuk aktivitas sosial di kota yang begitu kompleks. Melalui interaksi pengayuh dengan pemilik perusahaan becak, pelanggannya, dan juga orang-orang yang tinggal di kota, tercipta hubungan sosial yang saling membutuhkan. Henry Levebre menyebut aktivitas tersebut sebagai lived space, yaitu cara orang-orang yang tinggal dalam suatu ruang menciptakan hubungan. Sehingga terjadi aktivitas-aktivitas sosial yang menjadikan ruang Kota Indonesia "hidup".

Dalam level tukang becak, secara umum mereka merupakan kaum marjinal di kota. Namun, pada periode ini keberadaannya teramat sentral. Melalui tenaga yang ia miliki, kota yang membutuhkan sarana transportasi dapat di atasi. Transportasi diperoleh melalui hubungan pengayuhnya dengan pemilik perusahaan becak. Mayoritas dari pemilik perusahaan merupakan orang-orang Tionghoa, sedangkan pengayuh becak mayoritas orang Jawa. Hubungan antara kedua ras yang berbeda pada waktu itu layaknya simbiosis mutualisme. Meskipun dalam segi ini orang Indonesia memiliki level dibawah orang Tionghoa (selaku majikan), karena sudah menyewakan. Namun berkat hubungan itu kota tetap berjalan dengan segala kapasitas terbatasnya.

\section{Jalanan sebagai Lokasi Sejarah Keseharian}

Melalui cerita tukang becak didapati pola-pola unik yang hanya dialami secara pribadi oleh pengayuhnya di jalanan-jalanan kota. Secara umum jalanan merupakan akses yang menghubungkan suatu tempat ke tempat lain. Namun berkat hubungan pengayuh becak dengan pelanggan yang mereka temui di jalan, seringkali ketidakpastian berupa penipuan dan tindak pencurian terjadi. Sehingga, jalanan bukan hanya akses perhubungan namun juga representasi ruang yang rentan terhadap tindak kejahatan. ${ }^{9}$

Pada tahun 1950an hingga 1970an, melalui jalanan tukang becak mengalami fenomena menemukan cinta di jalan. Berdasarkan dari cerita beberapa kasus tukang becak, ada dua kemungkinan dalam menemukan

9) Secara lebih detail terangkum dalam Skripsi Eka Rahayu Manggarsari (Alumnus Program Studi S1 Ilmu Sejarah, FIB, UGM), dengan judul Kota Dikayuh oleh Kaki Manusia: Becak dalam Perkembangan Masyarakat Urban di Yogyakarta 1950an-1970an. 
pasangan. Pertama, kasus menemukan pasangan di kampung halaman (desa), kedua, pasangan yang mereka jumpai di jalan. Dalam hal percintaan, kasus menemukan pasangan di jalan lebih sering mereka alami. Hal tersebut berkaitan dengan kegiatan sehari-hari mereka yang lebih sering dilalui di jalanan. Bahkan kegiatan reproduksi seperti, makan, tidur, hingga berbagai interaksi dilakukan dalam ruang tersebut. Tidak jarang kasus semacam menemukan cinta di jalan juga sering terjadi.

Melalui pemaparan pada paragraf sebelumnya, uang-ruang kota yang seringkali tidak kita sadari arti pentingnya, menjadi menarik diulas dalam sebuah narasi besar. Melihat lingkup kecil ruang kota sebagai sebuah pendekatan untuk mengetahui cara kerja kota dalam level renik. Sebagai orang Indonesia kita harus sadari, hingga saat ini kota merupakan magnet utama berbagai kegiatan. Namun, ada suatu periode dimana tenaga manusia naik ke tingkat yang lebih sentral. Untuk itu, bukankah menarik mengulas kehidupan mereka untuk kita kenang dan memberi mereka ruang bercerita. Karena fenomena semacam ini benar-benar terjadi di masa lalu dan inilah rerepresentasi wajah Kota Indonesia tahun 1950an hingga 1970an.

\section{Kesimpulan}

Eksplorasi penulisan sejarah kota menggunakan perspektif pengayuh transportasi publik pada tahun 1950an hingga 1970an merupakan hal yang dicoba untuk diimplementasikan melalui penelitian ini. Hasilnya menguji sejauh mana pendekatan tersebut mampu membuka mata kita untuk memahami ruang-ruang kota dalam satu periode sejarah dimana tenaga manusia itu sangat sentral. Sedangkan, image umum yang seringkali muncul jika membicarakan pengayuh becak atau tukang becak ialah "orang miskin", "terbelakang”, "kumuh", dan "pengganggu stabilitas kota”. Padahal hal tersebut tidak sepenuhnya benar.

Sudah saatnya pendekatan semacam ini diaplikasikan. Sejauh mana hal ini akan berlabuh, jawabannya ialah sejauh kemauan dan usaha penulis untuk mengeksplorasi. Bagaimanapun hasil yang diperoleh dalam penelitian ini, inilah representasi wajah Kota Indonesia tahun 1950an hingga 1970an, dimana tenaga manusia memiliki peran yang sentral dikota. Sedangkan untuk masalah sumber, bahwa "no document no history" dengan pendekatan yang diajukan oleh Paul Thompson "we can create history through oral history". Melalui metode tersebut, setidaknya tulisan ini berusaha memberi panggung bagi pahlawan-pahlawan dari kalangan biasa yang tidak tercatat dalam dokumen manapun, namun turut menjaga keberlangsungan Kota. Sehingga penulisan sejarah Kota Indonesia semakin adil dan beragam. 


\section{Referensi}

\section{Arsip, Sumber Resmi Tercetak, dan Sumber Internet}

BPAD Daerah Istimewa Yogyakarta, Laporan Sekretariat Pemerintah DIY, Tahun 1958.

BPAD. Pendjelasan Peraturan Daerah Kotapradja Jogjakarta. No: 16 Tahun 1960 Tentang: Betjak jang menggunakan djalan umum di Daerah Kotapradja Jogjakarta.

KITLV Digital Media Library. Rij wachtende betjak in een winkelstraat te Yogyakarta, https://www.kitlv.nl. Diakses pada 22 November 2016, Pukul. 07:06 WIB.

KITLV Digital Media Library - Wachtende betjak op Java, vermoedelijk te Yogyakarta, https://www.kitlv.nl. Diakses pada 22 November 2016, Pukul. 07:15 WIB.

KITLV Digital Media Library - Wachtende bestuurder slaapt in zijn betjak in een winkelstraat te Yogyakarta, https://www.kitlv.nl. Diakses pada 22 November 2016, Pukul. 07:24 WIB.

Badan Pusat Statistik (BPS). Statistik Perkembangan Kendaraan Bukan Bermotor 19591961.

Biro Pusat Statistik (BPS). Sensus Penduduk 1961 \& 1971.

Badan Pusat Statistik (BPS). Statistik kendaraan bukan bermotor tiap dasting II DIY 1961.

Badan Pusat Statistik (BPS). Statistik kendaraan bermotor DIY 1961.

Badan Pusat Statistik (BPS) DIY, Laporan D.L.L.A.J.R Daerah Istimewa Yogyakarta tahun 1972-1978. Jumlah Kendaraan Tidak Bermotor Daerah Istimewa Yogyakarta 1972-1974.

Badan Pusat Statistik (BPS) Jakarta.Sensus Penduduk tahun 1971.

Badan Pusat Statistik (BPS) Daerah Istimewa Yogyakarta. Statistik Penerimaan uang dalam bentuk Plombir tahun 1967.

Abeyaskere, Susan. Jakarta: A history. Review oleh John N. Miksic, Journal of Southeast Asian Studies, Vol.20, No.1.

Akbar, Jay. Mengayuh Sejarah Becak, https://historia.id. Diakses pada 4 Juni 2018, Pukul. 07:30 WIB.

A, Lubis. Lusiana. Komunikasi Antarbudaya Tionghoa dan Pribumi dalam Penggunaan Bahasa, (Jurnal Ilmu Komunikasi, Volume 10, Nomor 3, Agustus 2012).

Ananjaya, Asep. “Tiga Roda Kembali Berdecit”. www.era.id. Diakses pada 29 Mei 2018, Pukul. 19:00 WIB.

Assistance Team on Fiscal Decentralization for the Minister of Finance, Republik of Indonesia. "Indonesia's Intergovernmental Transfer: Response on Future Demographic and Urbanization Shifts", dalam https://www.dsfindonesia.org. Diakses pada 1 Maret 2018, Pukul. 08:09 WIB.

Bakarbessy, Leonora \& Sri Handajani. Kewarganegaraan Ganda Anak dalam Perkawinan Campuran dan Implikasinya dalam Hukum Perdata Internasional. Volume XVII No. 1 Tahun 2012. Edisi Januari.

"betja terug", dalam www.delpher.nl. Diakses pada 31 Mei 2018 ,Pukul. 13:20 WIB.

Budi, Langgeng. Sulistyo, Permasalahan Sosial Perkotaan pada Periode Revolusi: Kriminalitas di Yogyakarta 1947-1948. (Jurnal Lembaran Sejarah Vol. 1, No.2, 1997/1998 dalam Jurnal UGM, https://jurnal.ugm.ac.id. Diakses pada 12 Febuari 2019, Pukul. 15:55 WIB.

Damayanti,Vivin Retno. "Proses Industrialisasi di Indonesia dalam Perspektif Ekonomi Politik". (Jurnal of Indonesian Applied Economics, Vol. 2, No 1 Mei 2008) dalam https://www.jiae.ub.ac.id. Diakses pada 6 Januari 2019, Pukul. 10:04 WIB. 
Erman, Erwiza. "Penggunaan Sejarah Lisan dalam Historiografi Indonesia”. Jurnal Masyarakat \& Budaya, Volume 13 No. 1 Tahun 2011, dalam https://www.pmb. lipi.go.id. Diakses pada 15 Maret 2019, Pukul. 14:55 WIB.

Fryer, D. W., "Jogjakarta: Economic development in an Indonesian city state" Economic development and cultural change, vol.7 No.4 (Juli, 1959), http:// www.jstor.org/stable. Diakses pada 5 Maret 2019, Pukul. 13:01 WIB.

Jellinek, Lea. Seperti Roda Berputar: Perubahan Sosial Sebuah Kampung di Jakarta. (Jakarta: LP3ES, 1995), dalam www.era.id. Diakses pada 29 Mei 2018, Pukul. 19:00 WIB.

Matanasi, Petrik. Riwayat Becak: Dari Zaman Meiji sampai Bang Ali www.tirto.id. Diakses pada 28 Mei 2018, Pukul. 09:13 WIB.

Muntholib, Abdul. Melacak akar Rasialisme di Indonesia dalam Perspektif Historis. Artikel Jurnal Forum Ilmu Sosial (Desember 2008), dalam https://www.neliti. com. Diakses pada 16 Januari 2019, Pukul. 15:23 WIB.

Padmo, Soegianto. "Beberapa Hal Tentang Kajian Sejarah Sosial-Ekonomi Indonesia: Sebauh Survai”. (Jurnal Humaniora, No.10, Januari-April, 1999) dalam https:// www.jurnal.ugm.ac.id. Diakses pada 3 Maret 2019, Pukul. 12:23 WIB.

Pamungkas, Arie Setyaningrum.”Produksi Ruang dan Revolusi Kaum Urban Menurut Henri Levebvre", (11 Januari 2016), https://www.indoprogress.com. Diakses pada 10 Januari 2019, Pukul. 07:16 WIB.

Sejarah UII dan UIN Hingga Hasrat Mewujudkan UII", https:/ www.tirto.id \& "Titik Perjalanan Sejarah UII" https://www.uii.ac.id Diakses pada 18 Febuari 2019, Pukul. 10:59 WIB.

"Sejarah Universitas Gadjah Mada", dalam https://www.ugm.ac.id, Diakses pada 18 Febuari 2019, Pukul. 11:15 WIB.

“Sejarah: 1951-1960 Periode Rintisan”, dalam https://www.uin-suka.ac.id, Diakses pada 18 Febuari 2019, Pukul. 11:35 WIB.

Sejarah Universitas Sanata Dharma", dalam https://www.usd.ac.id, Diakses pada 18 Febuari 2019, Pukul. 12:06 WIB.

Sindo, Fandi. "Sisa Kejayaan Becak di Yogyakarta”. https://www.kompasiana.com. Diakses pada 12 Januari 2019, Pukul. 19:03 WIB.

Suradi."Peran Sektor Informal dalam Penanggulangan Kemiskinan. Jurnal Informasi”, (No.03, Tahun 2011), www.neliti.com. Diakses pada 9 Januari 2019, Pukul. 17:13 WIB.

Oktavianti, Apriliya, Hotel Merdeka. https://www.situsbudaya.id, 11 Oktober 2017. Diakses pada 28 Febuari 2019, Pukul. 17:30 WIB.

https://www.b2w-indonesia.or.id, Diakses pada 19 Januari 2019, Pukul. 09:08 WIB.

\section{Buku, Makalah, dan Tulisan IImiah}

Ahimsa, Heddy Shri. 1977. Kisah Kehidupan Keluarga Ngadimin seorang pengemudi becak. Yogyakarta: LPSK Universitas Gadjah Mada.

------ 1977. Kisah Kehidupan Keluarga Rakhim seorang pengemudi becak. Yogyakarta: LPSK Universitas Gadjah Mada.

- 1978. Kisah Kehidupan Keluarga Tukiran seorang pengemudi becak. Yogyakarta: LPSK Universitas Gadjah Mada.

Azuma, Yoshifumi. 2001. Abang Beca: Sekejam-kejamnya Ibu Tiri Masih Lebih Kejam Ibukota. Jakarta: Pustaka Sinar Harapan

Basundoro, Purnawan. dalam Artikel Orasi Ilmiah Dies Natalis Universitas Airlangga 
ke-59, "Perebutan Ruang Kota: Problem Masa Lalu, Masa Kini, dan Masa Depan Perkotaan di Indonesia”. Senin, 11 November 2013. Departemen Ilmu Sejarah, Fakultas Ilmu Budaya. Universitas Airlangga.

Basundoro, Purnawan. 2012. Pengantar Sejarah Kota. Yogyakarta: Penerbit Ombak. -------- 2012. Minyak Bumi dalam Dinamika Politik dan Ekonomi Indonesia 19501960an. Surabaya: Airlangga University Press.

Breman, Jan. 1995. "Kerja dan Hidup Sebagai Buruh tanpa Lahan di Pesisir Jawa" (Working and Living Conditions of landless labourers on the coastel are of Java) (pp.xxiii+ 46, Maret 1992) dalam Endang Suhendar, Tanah, Buruh, dan Usaha Kecil dalam Proses Perubahan: Kumpulan Ringkasan Hasil Penelitian Akatiga. (Bandung: Penerbit Yayasan Akatiga.

Childe, V. Gordon. 1952. What Happened in History. Harmondsworth Middlesen: A. Pelican Book.

Erman, Erwiza \& Ratna Saptari (ed). 2013. Dekolonisasi Buruh Kota dan Pembentukan Bangsa. Jakarta: Yayasan Pustaka Obor Indonesia.

-- 2013. "Kehidupan dan Politik Pengayuh Becak di Jakarta (1930-1960)", Erman, Erwiza \& Saptari, Ratna, Dekolonisasi Buruh Kota dan Pembentukan Bangsa. Jakarta: Yayasan Pustaka Obor Indonesia.

Fauziah, Siti Mahmudah Nur. 2018. Malioboro Tempo Doeloe: Sejarah Kehidupan Sehari-hari 1890-1950. Skripsi-S1. Jurusan Sejarah, Fakultas Ilmu Budaya, Universitas Gadjah Mada, Yogyakarta.

Geertz, Clifford. 1965. The Social History of an Indonesian Town. Cambridge: MIT Press.

Hermanu. 2013. Simplex Nganggo Berko. Yogyakarta: Bentara Budaya.

Ismawati, Rika Inggit. 2015Tunakarya di Negara Baru Merdeka: Pengangguran Revolusi Yogyakarta 1950-an , Tesis S-2, Fakultas Ilmu Budaya, Universitas Gadjah Mada.

Ingleson, John. 2013. Perkotaan Masalah Sosial \& Perburuhan di Jawa Masa Kolonial. Jakarta: Komunitas Bambu.

Jellinek, Lea. 1987. Seperti Roda Berputar: Perubahan Sosial Sebuah Kampung di Jakarta. Jakarta: LP3ES.

J.M Nas, Peter. 2007. Kota-Kota Indonesia Bunga Rampai. Yogyakarta: Gadjah Mada University Press.

Joga, Nirwono. 2017. Mewariskan Kota Layak Huni. Jakarta: Gramedia Pustaka Utama.

Kartodirdjo, Sartono. 1981). The pedicab in Yogyakarta: A study of low cost transportation and poverty problems. Yogyakarta: Gadjah Mada University Press.

Kawamura, Chiyo I.. "Peralihan Usaha dan Perubahan Sosial di Prawirotaman, Yogyakarta 1950an-1990an”, Tesis S-2, Jurusan Sejarah Fakultas Ilmu Budaya. Universitas Gadjah Mada, Yogyakarta.

Kuntowijoyo. 2003. Pengantar Ilmu Sejarah. Yogyakarta: Tiara Wacana.

Kusno, Abidin. 2010. The End of The Peasentry and the Politics of Peri-urbanization in an Indonesian Metropolis. Asia Research Institute: National University of Singapore.

Lubis, Firman. 2018. Jakarta 1950-1970. Jakarta: Komunitas Bambu.

Ma'arif, Samsul Persepsi. Wisatawan Terhadap Transportasi Wisata Andong Dan Becak Di Kawasan Malioboro Kota Yogyakarta 2013-2014. Tesis S-2, Fakultas Geografi, Universitas Gadjah Mada, Yogyakarta. 
Masjkuri, dkk. 1997. Sejarah Daerah Istimewa Yogyakarta. Yogyakarta: Depdikbud.

McGee, Terry. 1997. "The Emergence of Desakota Regions in Asia," in The Extended Metropolis Settlement Transtition in Asia, di edit oleh Norton Ginsburg, Bruce Koppel \& Terry McGee. Hawaii: University of Hawai Press.

Purwanto, Bambang. 2015. "Kekerasan dan Kriminalitas di Kota pada saat Transisi: Kotagede, Yogyakarta pada Akhir Masa Kolonial dan Awal Kemerdekaan”, dalam Colombijn, Freek, dkk, Kota Lama Kota Baru: Sejarah Kota-Kota di Indonesia. Yogyakarta: Penerbit Ombak.

"Conflict and coexsistence: Multicultural Images of Urban Yogyakarta in the First Half of Twentieth Century", Coexistence or Juxtaposition, (Yogyakarta: Department History of Gadjah Mada University)

Rahayu, Puji. "Fungsi Sosial Sepeda Onthel di Yogyakarta tahun 1950an-1970an", Tesis S-2, Jurusan Sejarah, Fakultas Ilmu Budaya, Universitas Gadjah Mada, Yogyakarta.

Rajagukguk, H.P. 2001. Peran Serta Pekerja dalam Pengelolaan Perusahaan. Jakarta: Yayasan Obor Indonesia.

Rimsky, Judisseno. 2017. Aktivitas dan Kompleksitas Kepariwisataan: Suatu Tinjauan tentang Kebijakan Pengembangan Kepariwisataan. Jakarta: PT Gramedia.

Riva’i, Muhammad. Berebut Rezeki Di jalan:Sejarah Sosial, Kelompok Marjinal Di Kota Medan, 1920an-1950an. Tesis S-2, Jurusan Sejarah, Fakultas Ilmu Budaya, Universitas Gadjah Mada, Yogyakarta.

Soemardjan, Selo. 2009. Perubahan Sosial di Yogyakarta. Jakarta: Komunitas Bambu. Soerjadi. 1961. "Kedudukan Buruh dan Majikan dalam Hubungan Perburuhan Pancasila”. Fakultas Hukum. Universitas Airlangga. Surabaya.

Suryo, Djoko. 2015. "Pendudukan dan Perkembangan Kota Yogyakarta 1900-1990", dalam Colombijn, Freek, dkk, Kota Lama Kota Baru: Sejarah Kota-Kota di Indonesia. Yogyakarta: Penerbit Ombak.

Surjomihardjo, Abdurrachman. Kota Yogyakarta Tempo Doeloe: Sejarah Sosial 18801930, (Jakarta: Komunitas Bambu. 2008).

Suparman. 2000. "Deskripsi kehidupan tukang becak di kawasan Malioboro". Tesis S-2. Jurusan Ilmu Sosiatri, APMD.

Sunaryo, Rony G., Nindyo Soewarno, Bakti Setiawan, "Pengaruh Kolonialisme Pada Morfologi Ruang Kota Jawa Periode 1600-1942”. (Yogyakarta: Seminar Nasional Riset Arsitektur dan Perencanaan (SERAP 3), Teknik Arsitektur dan Perencanaan Universitas Gadjah Mada. 2014).

Thompson, Paul. 1978. The Voice of The Past: Oral History. New York: Oxford University Press.

Usman, Sunyoto. 2015. Perubahan Sosial: Esai-Esai Sosiologi. Yogyakarta: Pustaka Pelajar.

Wertheim, W.F. 1999. Masyarakat Indonesia dalam Transisi: Studi Perubahan Sosial. Yogyakarta: Tiara Wacana.

Wijayanto, Duto. "Konflik Kekerasan dan Kriminalitas di Ibukota Republik Indonesia Yogyakarta tahun 1946-1955”. Tesis S-2. Jurusan Ilmu Sejarah, Fakultas Ilmu Budaya, Universitas Gadjah Mada, Yogyakarta.

Wolf, Eric R.. 1982. Europe and teh People Without History. Calfornia:University of California Press.

Yogya, Harry Van. 2011. The Becak Way, Ngudroso Inspiratif di Jalan Becek. Solo: Metagraf. 
Yunus, Nizam A.. 1978. Hal Ikhwal Penduduk Daerah Istimewa Yogyakarta. Jakarta: Lembaga Demografi, Fakultas Ekonomi, Universitas Indonesia.

\section{Koran dan Majalah}

Kedaulatan Rakyat tahun 1976.

Kedaulatan Rakyat tahun 1964.

Pustaka dan Budaja, No. 8. Desember 1960.

\section{Wawancara}

\begin{tabular}{|c|c|}
\hline \multicolumn{2}{|c|}{ Informan $1(14 / 09 / 2018)$} \\
\hline Nama & : Mardi \\
\hline \multicolumn{2}{|c|}{ Umur/Th.lahir : -/1950an } \\
\hline Alamat & : Cawas, Klaten \\
\hline Th.Becak & : 1966 \\
\hline Lokasi & : Pasar Beringharjo \\
\hline \multicolumn{2}{|c|}{ Informan $2(15 / 09 / 2018)$} \\
\hline Nama & : Poniman \\
\hline Umur/Th. & $r:-$ \\
\hline Alamat & : Wonogiri \\
\hline Th.Becak & $: 1963$ \\
\hline Lokasi & $\begin{array}{l}\text { : Pasar Beringharjo \& } \\
\text { Malioboro }\end{array}$ \\
\hline
\end{tabular}

Informan $3(15 / 09 / 2018)$

Nama : Sugiono

Umur/Th.lahir : -

Alamat : Panggungharjo, Sewon, Bantul

Th.Becak : 1967

Lokasi : Pasar Beringharjo

Informan 4 (16/09/2018)

Nama : Prapto Utomo

Umur/Th.lahir : -/1952

Alamat : Tamanan, Banguntapan, Bantul

Th.Becak : 1969

Lokasi : Pasar Beringharjo

Informan 5 (16/09/2018)

Nama : Suripto

Umur/Th.lahir : -/1947

Alamat : Kuweni, Rt.06, Panggungharjo, Sewon, Bantul

Th.Becak : 1968

Lokasi : Pasar Beringharjo

Informan $6(19 / 09 / 2018)$

Nama : Sugiwanto

Umur/Th.lahir : -/1947

Alamat : Randublang, Bantul

Th.Becak : 1970

Lokasi : Pasar Beringharjo
Informan 7 (28/09/2018)

Nama : Panut

Umur/Th.lahir : 73 tahun/1945

Alamat : Wates, Yogyakarta

Th.Becak :1950an

Lokasi : Pasar Kranggan

Informan 8 (28/09/2018)

Nama : Mardiyanto

Umur/Th.lahir : -/1960

Alamat : Terban, Yogyakarta

(Kontrak)

Th.Becak : 1973

Lokasi : Pasar Kranggan

Informan $9(29 / 09 / 2018)$

Nama : Agus Ponimin

Umur/Th.lahir : -

Alamat : : Tegalrejo, Yogyakarta

Th.Becak : 1972

Lokasi : : Hotel Phoenix (dulu Hotel Merdeka)

Informan 10 (29/09/2018)

Nama : Slamet Pujosumarto

Umur/Th.lahir : -/1955

Alamat : : Sebelah barat Pasar Bantul

Th.Becak : 1971

Lokasi : Pasar Beringharjo

Informan $11(4 / 10 / 2019)$

Nama : Augustine Chen

Umur/Th.lahir : -

Alamat : Sewon, Bantul, Yogyakarta

Th.Berdirinya

Perusahaan : 1974

Lokasi : : Sewon, Bantul, Yogyakarta

Informan 12 (5/11/2018)

Nama : Madilasono (Penjual Sayur)

Umur/Th.lahir : -

Alamat : Ngadilasono, Yogyakarta

Th. Berjualan : 1945

Lokasi : Pasar Beringharo \& Pasar Kranggan 